\title{
Acta didactica 10 år
}

Acta didactica er 10 år, og det er med stor glede at vi kan presentere dette jubileumsnummeret, som består av inviterte artikler skrevet av forskere med spesialkompetanse på en rekke ulike fagfelt innen fagdidaktikk og lærerutdanning. Jubileumsutgaven publiseres på tiårs-dagen for tidsskriftets aller første utgave, som ble publisert 4. oktober 2007. Dagens utgave markerer dermed ti år med et dynamisk tidsskrift som har vært og er i stadig vekst og utvikling.

Samtidig med publiseringen av jubileumsutgaven, arrangerer ADNO og tidsskriftets vertsinstitusjon, Institutt for lærerutdanning og skoleforskning (ILS), et lanseringsseminar på Universitetet i Oslo. En egen jubileumskomité har hatt ansvar for å planlegge jubileumsseminaret så vel som innholdet i jubileumsnummeret. Komiteen begynte sitt arbeid våren 2016 og har bestått av instituttleder ved ILS, professor Rita Hvistendahl, forskningsleder ved ILS, professor Erik Knain, tidligere ansvarlig redaktør for ADNO, professor Glenn Ole Hellekjær (ILS), layout-redaktør i ADNO, rådgiver Toril Eggen (ILS), gjesteredaktør for jubileumsnummeret, førstebibliotekar Ingerid Straume (Universitetsbiblioteket i Oslo) og nåværende ansvarlig redaktør for ADNO, førsteamanuensis Eva Thue Vold (ILS). Ingerid Straume og Eva Thue Vold har hatt ansvaret for å redigere jubileumsnummeret. Dette redaksjonelle samarbeidet mellom Universitetsbiblioteket (UB) og ILS gjenspeiler det mer generelle samarbeidet som finnes mellom ADNO og ILS på den ene siden og UB på den andre: UB administrerer UiOs FRITT-tjeneste, som er det tekniske miljøet som er vert for tidsskriftet. Samtidig har Ingerid Straume gjennom mange år vært UBs fagreferent for fagdidaktikk og på den måten vært den primære kontaktperson ved UB for mange av forskerne ved ILS.

\section{Innhold i jubileumsutgaven}

Jubileumsnummeret åpner med en gjennomgang av ADNOs tiårige historie, ført i pennen av de tre tidligere ansvarlige redaktørene: Rita Hvistendahl, Jon Magne Vestøl og Glenn Ole Hellekjær. I artikkelen gjør de rede for tidsskriftets utvikling fra etableringen i 2007 gjennom tre faser: oppstart, konsolidering og ekspansjon. Fortellingen vitner om et tidsskrift som helt klart har fylt et behov når det gjelder publiseringskanal: Fra en sped begynnelse, utviklet tidsskriftet seg raskt til å bli en svært viktig informasjonskanal for fagdidaktikk- og lærerutdanningsmiljøene i Norge. I dag opplever ADNO en rekordstor pågang av artikler, og nedlastingstallene tyder på at tidsskriftet er mye lest.

Etter denne åpningsartikkelen følger ti artikler som er gruppert i tre seksjoner: 1) fagdidaktiske overblikk, 2) tre nylig innførte tverrfaglige temaer i læreplanverket, 3) utvalgte smakebiter fra aktuell forskning ved ADNOs 
hjeminstitusjon. I del 1 tar vi sikte på å gi noen fagdidaktiske overblikk, eller state of the art-oppsummeringer, for ulike felt innen de tre store faggruppene som det undervises i og forskes på ved ILS: realfag, språkfag og samfunnsfag. Vi ønsket et nordisk fokus på disse overblikksartiklene og vi har derfor valgt å gi ordet til forskere fra ulike nordiske land som hver på sin måte gjør opp status for utvalgte temaer eller områder innen sine respektive fagdidaktiske felt, i et nordisk perspektiv. Fra realfagsdidaktikken har vi invitert naturfagsdidaktikerne Jens Dolin og Jan Alexis Nielsen, begge fra Københavns universitet. De tar for seg sammenhengen mellom vurderingsformer og utvikling av kompetanser i naturfag. I artikkelen skisserer de kort de siste 40-50 års utvikling i naturfagene fram til dagens fokus på undersøkelsesbasert undervisning og utvikling av kompetanser. Deretter diskuterer de hvordan tradisjonelle vurderingsformer ikke nødvendigvis er egnet til å fange inn de kompetansene man ønsker å teste. Gjennom å vise til en rekke prosjekter og forsøk, argumenterer de for større grad av samsvar mellom naturfagenes formål, pedagogikk og vurderingsformer.

Det språkdidaktiske perspektivet ivaretas av Gudrun Erickson fra Göteborgs universitet og Heini-Marja Pakula fra Åbo universitet. Deres artikkel tar for seg Det felles europeiske rammeverket for språk (Europarådet, 2001). Forfatterne diskuterer hvilken rolle dette rammeverket og tilhørende dokumenter har fått for læring, undervisning og vurdering i språkfag i de ulike nordiske land. Artikkelen bygger på data fra sentrale informanter i alle de nordiske land og beskriver og problematiserer hvordan Rammeverket er blitt mottatt og tatt i bruk i de forskjellige landene.

Geir Skeie fra Universitetet i Stavanger og Stockholms universitet har kartlagt utviklingstrekk i det religionsdidaktiske forskningsfeltet i form av en nordisk litteraturgjennomgang som også inkluderer konferanser. Der forskningen tidligere dreide seg om religionsundervisning og kristendommens rolle i et stadig mer pluralistisk samfunn, er dagens situasjon preget av mangfold som perspektiv og fenomen. Religions- og livssynsmangfoldet som preger mange nordiske klasserom gir både utfordringer og muligheter, for eksempel til å arbeide med verdispørsmål på tvers av fag. I tillegg til å kartlegge nasjonale variasjoner, viser forfatteren hvordan både forskningsfeltet og skolens religionsog livssynsfag bærer i seg spenninger og muligheter for videreutvikling.

Del 2 tar opp spørsmål knyttet til de tre nylig innførte tverrfaglige temaene i det norske læreplanverket: Folkehelse og livsmestring, Demokrati og medborgerskap og Bærekraftig utvikling (Kunnskapsdepartementet, 2017). Forfatterne av artiklene i denne seksjonen ble utfordret til å svare på hvordan man kan arbeide med disse temaene i skolen i og på tvers av fag. Først ut er Ingrid Lund fra Universitetet i Agder, Anne Helgeland fra Sørlandet sykehus og Velibor Bobo Kovač fra Universitetet i Agder, som har tatt for seg temaet Folkehelse og livsmestring i lys av ett av vår tids største oppvekstproblemer: mobbing i skolen. Som forfatterne argumenterer, kan mobbing forstås som sammensatte sosiale prosesser der voksne er ansvarlige, noe som gjør det mulig 
å belyse problemet i en større sammenheng der blant annet skolekultur og læringsmiljø spiller viktige roller. Barns opplevelse av livsmestring forutsetter tilhørighet i et sosialt fellesskap, og som artikkelen viser, kan folkehelse og livsmestring være et inntak til å arbeide med en rekke meningsfylte spørsmål i og på tvers av fag.

Hva slags forståelse av demokratisk medborgerskap er vi på vei mot i den norske skolen? Dette er spørsmålet Kjetil Børhaug fra Universitetet i Bergen stiller i sin gjennomgang av idégrunnlaget for Ludvigsenutvalgets utredning, Fremtidens skole (NOU 2015: 8) og stortingsmeldingen om fagfornyelse (Kunnskapsdepartementet, 2016). Med utgangpunkt i samfunnsfagdidaktiske og statsvitenskapelige perspektiver, viser forfatteren hvordan både deltakelsesbegrepet og forståelsen av det politiske systemets betydning inneholder uklarheter og spenninger som - i sin foreliggende form - trekker i retning det han kaller avpolitisert individualisme, der samhandlingskompetanse på mikronivå betraktes som viktigere enn deltakelse i det politiske systemet der avgjørelser skjer.

I artikkelen om Bærekraftig utvikling, spør Astrid Sinnes, NMBU og Ingerid Straume, UiO hvordan den nye satsingen på utdanning for bærekraftig utvikling kan gi temaet en mer aktiv rolle i fremtidens skole. Forfatterne understreker at for å lykkes med å ruste elevene for å leve bærekraftige liv i framtidens samfunn, er det viktig at de ikke bare lærer teori om hva som er bærekraftig utvikling, men at de også får muligheten til å omsette denne teorien i praksis gjennom handlinger og erfaringer i skolehverdagen. Samtidig advarer forfatterne mot å tro at det nye fokuset på kjerneelementer i fag (jf. Kunnskapsdepartementet, 2016) i seg selv er tilstrekkelig for å utvikle den nødvendige kompetansen på bærekraftig utvikling, og de foreslår i stedet å ta utgangspunkt i nåtidens store spørsmål.

Del 3 er satt av til smakebiter fra aktuell forskning ved ADNOs hjeminstitusjon, Institutt for lærerutdanning og skoleforskning og Det utdanningsvitenskapelige fakultetet ved Universitetet i Oslo. ADNO har vært drevet av ILS i 10 år, og for mange av institusjonens forskere har tidsskriftet vært et naturlig sted å publisere sin forskning. Vi har hentet fram eksempler fra to hovedområder som begge er sentrale for ILS og for ADNO: Lærerutdanning og Undervisning og læring i fag. Under Lærerutdanning byr vi på to artikler. Først ut er Sigrid Blömeke fra Centre of Educational Measurement (CEMO), UV-fakultetet og medforfatterne Jessica Hoth og Gabriele Kaiser, henholdsvis fra universitetene i Vechta og Hamburg. De presenterer en longitudinell studie av tyske grunnskolelærere og deres kompetanseutvikling på matematikkfeltet gjennom lærerutdanning og de første årene i jobb. Studien fokuserer både på utvikling av kunnskap i matematikk, matematikkdidaktikk og praksisferdigheter. Forfatterne diskuterer hvilken rolle bl.a. skoleresultater spiller for lærernes kompetanseutvikling, og reiser på bakgrunn av dette spørsmål om utvalgskriterier ved starten av lærerutdanningen og hvilke muligheter studenter 
har til å lære seg matematikk og matematikkdidaktikk under grunnskolelærerutdanningen. Videre diskuterer de på hvilken måte resultatene fra Tyskland har betydning for norsk lærerutdanning.

Det internasjonale perspektivet står også sentralt i forskningsprosjektet Coherence and Assignments in Teacher Education, CATE. Kirsti Klette (ILS), Karen Hammerness (American Museum of Natural History, New York) og Inga Staal Jenset (ILS) forsker på muligheter for praksisbasert læring i lærerutdanningsprogrammer i så ulike kontekster som Finland, Norge, California, Chile og Cuba. Ønsket om en mer praksisnær lærerutdanning står sterkt i store deler av verden, og CATE-prosjektet har utviklet et komparativt analytisk rammeverk for å kunne studere hvordan ulike typer læring gjennom praksis er - og kan bli - integrert i lærerutdanningen i de ulike landene.

Delen «Undervisning og læring i fag» inneholder også to artikler, som begge på hver sin måte fokuserer på utvikling av elevers literacy-ferdigheter. Kirsti Klette, Marte Blikstad-Balas og Astrid Roe, alle fra ILS, presenterer det NFRstøttede prosjektet Linking Instruction and Student Achievement (LISA). Prosjektet er originalt og nyskapende i det at det tar sikte på å undersøke sammenhenger mellom målbar faglig fremgang i lesing og regning og lærerens undervisning. Sammenhengene undersøkes gjennom en kombinasjon av ulike typer datakilder: elevspørreskjemaer, klasseromsobservasjoner og målt fremgang på nasjonale prøver i lesing og regning. Forfatterne argumenterer for verdien av videodata når det gjelder å studere undervisningspraksiser og deler noen av prosjektets tidlige forskningsfunn.

Den neste artikkelen, forfattet av Erik Knain, Tobias Fredlund, Anniken Furberg, Ketil Mathiassen, Kari Beate Remmen og Marianne Ødegaard, alle fra ILS, dreier seg om literacy knyttet til naturfaglig og -vitenskapelig forståelse, nærmere bestemt hvordan ulike representasjoner som grafer, tegninger, animasjoner, gester og skrift kan brukes aktivt for å utvikle elevers forståelse og mestring. Forsknings- og utviklingsprosjektet Representasjon og deltakelse i naturfag (REDE) har som formål å utvikle undervisningsressurser knyttet til begrepslæring, naturvitenskapens egenart og læring gjennom arbeid med sosiovitenskapelige spørsmål (SSI). Artikkelen gir en innføring i det teoretiske rammeverket knyttet til begrepene «scientific literacy» og «tredje rom», og videreutvikler dette i form av designprinsipper for undervisningsopplegg på ungdoms- og videregående trinn. I tillegg viser forfatterne hvordan multimodal analyse og interaksjonsanalyse er egnet til å belyse de aktuelle arbeidsmåtene. Eksemplene som er valgt gjelder elevers eksperimenter med drivhuseffekten og, som eksempel på et sosiovitenskapelig tema, spørsmålet om fortsatt (norsk) oljeutvinning. 


\section{Veien videre for Acta didactica}

Jubileumsnummeret gjenspeiler på mange måter den retningen Acta didactica vil bevege seg i i tiden framover: Med det sterke nordiske fokuset i del 1, markerer vi at tidsskriftet er i ferd med å utvide horisonten og nedslagsfeltet ytterligere, i den forstand at vi blir et nordisk, mer enn et nasjonalt tidsskrift. Det er behov for et samlende, nordisk tidsskrift for fagdidaktisk forskning og forskning på lærerutdanning som spenner over hele bredden av skolefag. Slik utdanningsvitenskapelig forskning er ofte tett knyttet til skolesystemer og lovverk og derfor ikke alltid umiddelbart relevant for de store, internasjonale, engelskspråklige tidsskriftene. De nordiske landene er imidlertid i stor grad sammenlignbare når det gjelder utdanningssystemer og har mange felles problemstillinger. Acta didactica er et forum for deling av slik kunnskap.

I prosessen med å styrke det nordiske fokuset, har vi i det siste rekruttert flere medlemmer fra ulike nordiske land til både redaksjon og redaksjonsråd. Førsteamanuensis Anna Johnsson Harrie fra Linköping universitet begynte som områderedaktør for samfunnsfagsdidaktikk våren 2017, og førstemanuensis Simon Skov Fougt fra Professionshøjskolen Metropol i København begynner i disse dager som områderedaktør for profesjonsfaglig utvikling og IKT-basert didaktikk. Sammen med førsteamanuensis Crina Damsa, UiO, overtar han ansvaret for dette fagområdet etter førsteamanuensis Greta Gudmundsdottir, som etter hvert vil fase ut sin redaktørrolle i ADNO. Med Harrie og Fougts inntog i redaksjonen, er både svenske og danske institusjoner representert i tidsskriftets redaksjon.

Til redaksjonsrådet har vi også gleden av å ønske flere nye medlemmer velkommen. De nye medlemmene er rekruttert fra flere nordiske land: Professor Camilla Bardel fra Stockholms universitet, professor Jens Dolin fra Københavns universitet, førsteamanuensis Thurídur Jóhannsdóttir fra Universitetet på Island, professor Ritva Kantelinen fra Östra Finlands universitet, professor Håkan Larsson fra Gymnastik- och idrottshögskolan i Stockholm og førsteamanuensis Helle Pia Laursen fra Aarhus universitet, trer alle inn i redaksjonsrådet f.o.m oktober 2017. Av de eksisterende medlemmene er det flere som blir med oss videre; det gjelder Geir Afdal, Menighetsfakultetet/HiØ, Kjetil Børhaug, UiB, Anne Emstad, NTNU, Rune Herheim, HiB, Bodil Kleve, HiOA, Kjetil Knudsen, UiS og Lise Vikan Sandvik, NTNU. Andre velger å takke for seg etter mange års deltakelse: Anne Fyhn og Anne Stokke, begge UiT, Frøydis Hertzberg og Erik Knain, begge UiO, Hedvig Johannesen og Kaare Skagen, begge HiOA, Lise Kulbrandstad, INN og Ole-Einar Torkildsen, HiVo. Vi takker for innsatsen!

Redaksjonsrådets medlemmer, nye som gamle, vil hjelpe til med å spre informasjon om ADNO i sine respektive nettverk og land og de vil fungere som diskusjonspartner for områderedaktøren på det relevante fagfeltet. Vi har stor tro på at den nye spredningen i redaksjons- og redaksjonsrådsmedlemmer vil bidra 
til å videreutvikle ADNO som et sentralt tidsskrift for utdanningsvitenskapelig forskning innen ulike fag i Norden.

Utvalget og sammensetningen av artikler i jubileumsnummeret gjenspeiler også ADNOs primære fokusområder, som er undervisning og læring i og på tvers av fag og lærerutdanning og læreres profesjonsutvikling. Mens del 1 tar for seg undervisning i ulike fag, fokuserer del 2 på de tre nylig innførte tverrfaglige områdene i læreplanverket. Disse tre temaene blir uten tvil viktig i framtidas skole. Ved å inkludere disse temaene, signaliserer ADNO at vi ønsker å gi plass til aktuell og relevant forskning som vil spille en rolle når det gjelder å forme framtidas skole.

Også språkmessig gjenspeiler jubileumsnummeret den bredden vi fortsatt ønsker velkommen i ADNO. Tidsskriftet publiserer artikler på alle de skandinaviske språk, og tar i tillegg i mot artikler skrevet på engelsk. Skandinaviskspråklige artikler vil fortsatt utgjøre hoveddelen av det som publiseres i ADNO.

ADNO har siden oppstarten lagt vekt på fri og åpen tilgjengelighet og det er noe vi kommer til å fortsette med. Vi skal fortsatt være et såkalt platina open access tidsskrift, det vil si at vi verken tar abonnementsavgift eller forfatterbetaling. Men selv om tidsskriftet er fritt tilgjengelig for alle, vet vi at det er lett for lesere å drukne i det vellet av tidsskrifter og informasjonskanaler som fins. ADNO jobber derfor systematisk med synlighet. Blant annet vil vi søke om å bli registrert i flere internasjonale databaser over tidsskrift, slik at vi kan bli mer kjent og mer synlige internasjonalt. I tillegg er alle artikler nå utstyrt med en DOI, en digital object identifier, som er en permanent lenke til den aktuelle artikkelen, og som ytterligere forenkler tilgangen til og forbedrer synligheten av de publiserte artiklene. Vi har også innført en praksis med at det skal følge en kort forfatterbio med alle publiserte artikler. Dette gir leseren litt informasjon om hvem det er som skriver, og det gjør det lettere å knytte kontakt og faglige nettverk.

Den oppmerksomme ADNO-leser vil ha lagt merke til en rekke endringer på ADNOs nettsider den siste tiden, som alle er et ledd i å stake ut kursen for veien videre som beskrevet over. Innføring av DOI og forfatterbio er eksempler på dette. I tillegg er beskrivelsen av hovedfokus og spennvidde noe endret, for å tydeliggjøre ADNOs opprinnelige fokus på undervisning og læring i og på tvers av fag og på lærerutdanning. Forfatterinstruksen er oppdatert i en forkortet og forenklet versjon, men med tydelige krav, bl.a. til språkvask. ADNO opplever en gledelig økning i tilstrømmingen av artikler. Samtidig er denne økningen arbeidsmessig utfordrende for redaksjonen. Det betyr at vi må stille strengere krav til innsendte manuskripter, men først og fremst betyr det at vi utvider redaksjonen med nye medlemmer - derav de nylige tilføyingene under Redaksjon som beskrevet ovenfor - og at vi publiserer mer enn før. 


\section{Takk}

Til slutt vil redaksjonen rette en stor takk til forfatterne som har bidratt med artikler til denne jubileumsutgaven, og ikke minst, en stor takk til alle de anonyme fagfellene som har bidratt med nyttige innspill til, og konstruktiv kritikk av, de innsendte bidragene. Selv om denne spesialutgaven av ADNO består utelukkende av inviterte bidrag, har artiklene vært igjennom samme kvalitetssikringsprosess som normalt. Det vil si at bidragene har vært vurdert av to eksterne fagfeller i tillegg til en redaksjonell vurdering. Fagfellene tilhører en rekke utdanningsvitenskapelige miljøer i Norge og Sverige, og vi setter stor pris på det viktige arbeidet de har utført.

Da gjenstår det bare å ønske god leselyst!

Oslo 02.10.2017

Eva Thue Vold

Ansvarlig redaktør
Ingerid Straume

Gjesteredaktør

\section{Referanser}

Europarådet (Council of Europe) (2001). Common European Framework of Reference for Languages: Learning, teaching, assessment. Cambridge, UK: Cambridge University Press. http://www.coe.int/t/dg4/linguistic/cadre1_en.asp

Kunnskapsdepartementet (2016). Fag - Fordypning - Forståelse. En fornyelse av Kunnskapsløftet. (Meld. St. 28, 2015-2016). Oslo: Kunnskapsdepartementet. https://www.regjeringen.no/contentassets/e8e1f41732ca4a64b003fca213ae663b/no/pdfs/s $\underline{\text { tm201520160028000dddpdfs.pdf }}$

Kunnskapsdepartementet (2017). Overordnet del - verdier og prinsipper for grunnopplceringen. Oslo: Kunnskapsdepartementet.

https://www.regjeringen.no/contentassets/37f2f7e1850046a0a3f676fd45851384/overordnetdel---verdier-og-prinsipper-for-grunnopplaringen.pdf

NOU (2015: 8). Fremtidens skole - Fornyelse av fag og kompetanser. https://www.regjeringen.no/contentassets/da148fec8c4a4ab88daa8b677a700292/no/pdfs/ nou201520150008000dddpdfs.pdf. 